\title{
From sequences to enzymes: heterologous expression of genes from marine microbes
}

Angelica Severino ${ }^{1}$, Alessandro Coppola ${ }^{1}$, Monica Correggia ${ }^{1}$, Costantino Vetriani $^{2,3}$, Donato Giovannelli ${ }^{1,2,4,5,6}$ and Angelina Cordone ${ }^{1, *}$

1 Department of Biology, University of Naples Federico II, Naples, Italy

2 Department of Marine and Coastal Sciences, Rutgers University, New Brunswick, NJ, USA

3 Department of Biochemistry and Microbiology, Rutgers University, New Brunswick, NJ, USA

4 National Research Council - Institute of Marine Biological Resources and Biotechnologies CNR-IRBIM, Ancona, Italy

5 Earth-Life Science Institute, Tokyo Institute of Technology, Tokyo, Japan

6 Marine Chemistry \& Geochemistry Department - Woods Hole Oceanographic Institution, MA, USA

*corresponding author: angelina.cordone@unina.it

Running Head: Heterologous expression of protein-coding genes

\section{Abstract}

Heterologous expression is an easy and broadly applicable experimental approach widely used to investigate protein functions without the need to genetically manipulate the original host. The approach is used to obtain large quantities of the desired protein, which can be further analyzed from a biochemical, structural and functional perspective. The expression system consists of three main components: i) a foreign DNA sequence coding for the protein of interest; ii) a suitable expression vector; iii) a suitable host (bacterial, yeast or mammalian cells) which does not encode or express the protein of interest. Here we show how to apply an Escherichia coli-based expression system to overexpress protein encoding genes from marine microbes.

Keywords: E. coli, expression vector, heterologous expression, recombinant protein, uncultured microorganisms, metagenomes

\section{Introduction}

Heterologous expression refers to the expression of a gene into a host organism that does not naturally express the gene (1). This process allows the production and isolation of a protein of 
interest from difficult to grow or uncultured organisms to investigate the protein function and its biological implications (2). Conventional genetic platforms established for heterologous expression consist of bacterial, yeast, algal or mammalian cell systems. Bacterial heterologous hosts are the most desirable in terms of low-cost production and availability of genetic tools for gene cloning (3). Heterologous expression systems are widely used for large-scale production of proteins with significant biotechnological applications. One of the most famous examples is Taq DNA Polymerase, a well-known and widely used enzyme, initially isolated from its native host, Thermus aquaticus, in 1976 (4), and then cloned and overexpressed in Escherichia coli (5). Heterologous expression offers additional advantages besides the potential for high yields, including heterologous expression of genes obtained from uncultured microorganisms (6), metagenomes or Metagenome Assembled Genomes (MAGs) (7) obtained from diverse samples (e.g. marine water, sediments, fluids), as well as expression of ancestral reconstructed genes obtained from comparative genomic analysis (as reported in Chapter [From sequences to enzymes: comparative genomics to study evolutionary conserved protein functions in marine microbes]). This has the potential to unlock information from the large fraction of genes encoding hypothetical proteins (8). In marine microbiology, heterologous expression approaches can be coupled to comparative genomics methods to study the functions and the evolutionary history of genes of interest, providing insight into their biochemical, structural and functional properties.

Heterologous expression methods are well established in molecular biology, and it is achieved by cloning the DNA fragment, previously isolated from the organism or metagenome of interest, into a suitable expression vector and introducing the recombinant plasmid into a host that will provide the biochemical apparatus to generate and express the 'foreign' protein. E. coli is the most popular host used to express recombinant proteins for several reasons: i) it is easy to handle; ii) it grows rapidly; iii) it is easy to transform; iv) it does not have specific nutritional needs, and v) a large number of expression vectors are available for E. coli (3). These features make E. coli-based heterologous expression a feasible and versatile tool to probe marine functional diversity.

Here we illustrate how to apply a heterologous expression method to express a protein coding gene from marine microbes. Briefly, the target DNA is cloned downstream and in frame with a sequence that encodes an N-terminal polyhistidine tag (His-tag), under the control of a strong bacteriophage T7 promoter. The His-tag acts as a metal-binding domain essential for the subsequent protein purification step. E. coli BL21 (DE3) (Promega) is an ideal host for recombinant protein expression of $\mathrm{T} 7$ regulated genes because it contains the DE3 bacteriophage lambda lysogen $(\lambda \mathrm{DE} 3)$ that carries the T7 RNA polymerase gene under the lacUV5 control. Using Isopropyl- $\beta$-D-1-thiogalactopyranoside (IPTG), an allolactose analogue, it is possible to induce the expression of T7 RNA polymerase to express the gene cloned under the T7 promoter's control (3). The method requires several individual steps: (i) cloning and propagation of the recombinant expression vector, (ii) expression and extraction of the recombinant protein, (iii) detection of the recombinant protein by SDS-PAGE and western blotting analysis. 


\section{Materials}

\subsection{Making Escherichia coli DH5a and BL21 (DE3) chemically competent cells}

1. Sterile loops, $2 \mathrm{~mL}$ sterile tubes and $100 \mathrm{~mL}$ flasks.

2. A basket filled with ice.

3. Cuvette UV/VIS.

4. Tryptone-Yeast (TY) liquid medium (1 L final volume): $10 \mathrm{~g}$ Tryptone, $5 \mathrm{~g}$ Yeast extract, $8 \mathrm{~g} \mathrm{NaCl}$. Add into a cylinder containing at least $800 \mathrm{~mL}$ of deionized water and a small stirring magnet at the bottom. Mix until the components are completely dissolved and add water up to 1 litre. Autoclave before use.

5. Tryptone-Yeast (TY) agar plates: add $1.8 \%$ agar (w/v) to TY liquid medium and autoclave before use (see Note 1).

6. A fresh stock of $50 \mathrm{mM} \mathrm{CaCl}$ solution ( $500 \mathrm{~mL}$ final volume): add $2.77 \mathrm{~g}$ of $\mathrm{CaCl}_{2}$ into a becher containing $400 \mathrm{~mL}$ of water. Let it dissolve completely and add water up to $500 \mathrm{~mL}$. Autoclave before use (See Note 2).

7. $100 \%$ Glycerol (see Note 3).

8. E. coli DH5a glycerol stock.

9. E. coli BL21 ( $\lambda \mathrm{DE} 3)$ glycerol stock.

\subsection{Molecular cloning step}

1. $0.2 \mathrm{~mL}$ and $0.5 \mathrm{~mL}$ sterile tubes.

2. Template genomic or metagenomic DNA to be used to amplify the target protein encoding gene.

3. Taq DNA polymerase with proofreading activity with the appropriate buffer.

4. Forward and reverse primers targeting the $5^{\prime}$ and $3^{\prime}$ of the gene of interest (Note 4).

5. $10 \mathrm{mM} \mathrm{dNTP \text {. }}$

6. Sterile deionized $\mathrm{H}_{2} \mathrm{O}\left(\mathrm{ddH}_{2} \mathrm{O}\right)$.

7. Thermocycler.

8. pRSET-A expression vector (Invitrogen). 
9. Restriction endonucleases with appropriate buffers.

10. T4 ligase enzyme with appropriate buffer (Promega).

11. A tube rack.

12. Gel extraction kit (Qiagen).

13. PCR purification kit (Qiagen).

\subsection{Bacterial transformation}

1. $90 \mathrm{~mm}$ TY agar plates supplemented with ampicillin $(100 \mu \mathrm{g} / \mathrm{mL})$ (see Note 5).

2. TY liquid medium (see Note 3).

3. E. coli $\mathrm{DH} 5 \alpha$ or BL21 $\lambda \mathrm{DE} 3$ competent cells.

4. Plasmid DNA or ligation mix (product of 2.2 Molecular cloning step).

5. $1.5 \mathrm{~mL}$ sterile tubes.

6. A basket filled with ice.

7. A tube rack.

\subsection{Agarose Gel Electrophoresis}

1. Comb, gel tray and electrophoresis apparatus.

2. $1 \%$ Agarose gel, made in $1 \times$ TAE buffer and casted to size according to the gel tray used.

3. Ethidium bromide solution, molecular grade $(10 \mathrm{mg} / \mathrm{mL})$.

4. TAE 50×: 2 M Tris Base, $1 \mathrm{M}$ Glacial Acetic Acid, 0.5 M EDTA (pH 8.6) (see Note 7).

5. Loading buffer $6 \times(10 \mathrm{~mL}$ final volume): $0.25 \%$ bromophenol blue, $0.25 \%$ xylene cyanol, $30 \%$ glycerol, water.

6. UV light transilluminator. 


\subsection{DNA plasmid extraction}

1. TY liquid medium (see Note 3 ).

2. A basket filled with ice.

3. Ampicillin stock solution $(100 \mathrm{mg} / \mathrm{mL})$ (see Note 6).

4. Solution 1: $50 \mathrm{mM}$ glucose, $10 \mathrm{mM}$ EDTA, $25 \mathrm{mM}$ Tris Base-HCl, $\mathrm{pH} 8.0$ (see Note $3,7)$.

5. Solution 2: $0.2 \mathrm{M} \mathrm{NaOH}, 1 \% \mathrm{SDS}$ (see Note 3, 9).

6. $3 \mathrm{M}$ Sodium acetate $\mathrm{pH} 5.2(100 \mathrm{~mL}$ final volume). Add $24.6 \mathrm{~g}$ of sodium acetate to $80 \mathrm{~mL}$ of water. Adjust $\mathrm{pH}$ if needed and add water up to $100 \mathrm{~mL}$ (see Note 3).

7. Phenol:Chloroform:Isoamyl alcohol (25:24:1, v:v).

8. EtOH $100 \%$, EtOH $70 \%$ (see Note 10,15).

9. RNase A stock solution (10 mg/mL) (see Note 11).

10. Sterile $100 \%$ Glycerol

11. $1.5 \mathrm{~mL}, 2 \mathrm{~mL}$ and $15 \mathrm{~mL}$ sterile tubes.

\subsection{Protein expression and extraction}

1. E. coli BL21 (DE3) competent cells.

2. Recombinant plasmid (product of DNA plasmid extraction, section 2.5 ).

3. TY agar plate supplemented with Ampicillin (see Note 5).

4. TY liquid medium.

5. Ampicillin stock solution $(100 \mathrm{mg} / \mathrm{mL})$ (see Note 6).

6. Sterile loops.

7. $2 \mathrm{~mL}, 1.5 \mathrm{~mL}, 50 \mathrm{~mL}$ sterile tubes, and flasks.

8. Cuvette for UV/VIS.

9. IPTG stock solution $100 \mathrm{mM}$ (see Note 12).

10. PBS-Triton X-100 $1 \%$ solution (1 L final volume): $0.1 \mathrm{M} \mathrm{NaCl}, 15 \mathrm{mM} \mathrm{Na}_{2} \mathrm{HPO}_{4}$, $4.5 \mathrm{mM} \mathrm{NaH}_{2} \mathrm{PO}_{4}, 1 \%$ Triton X-100, $\mathrm{pH} 7.3$.

11. Dry ice-ethanol bath or liquid nitrogen. 
12. $37^{\circ} \mathrm{C}$ water bath.

\subsection{Bradford assay}

1. $2 \mathrm{~mL}$ tubes.

2. Cuvette for UV/VIS.

3. Pasteur pipettes.

4. Bovine Serum Albumin (BSA) stock solution $(0.1 \mathrm{mg} / \mathrm{mL})$.

5. Bradford reagent (1 L final volume): $100 \mathrm{mg}$ Coomassie Brilliant Blue G250, $50 \mathrm{~mL}$ $95 \%$ ethanol, $100 \mathrm{~mL} 85 \%$ (w/v) phosphoric acid, add $\mathrm{ddH}_{2} \mathrm{O}$ up to $1 \mathrm{~L}$.

6. Deionized $\mathrm{H}_{2} \mathrm{O}\left(\mathrm{ddH}_{2} \mathrm{O}\right)$.

7. Spectrophotometer UV/VIS.

\subsection{SDS-Polyacrylamide electrophoresis (SDS-PAGE)}

1. Glass plates, comb, spacer, casting gel apparatus.

2. Resolving gel (12.5\%) (10 mL final volume): $4 \mathrm{~mL} 30 \%$ Acrylamide, $2.6 \mathrm{~mL} 1 \mathrm{M}$ Tris Base-HCl pH 8.8, $100 \mu \mathrm{l} 10 \%$ SDS, $100 \mu \mathrm{l} 10 \%$ APS, $\mathrm{ddH}_{2} \mathrm{O}$ up to $10 \mathrm{~mL}, 5 \mu \mathrm{l}$ Tetramethylethylenediamine (TEMED) (see Note 13).

3. Stacking gel (5\%) (4 mL final volume): $670 \mu 130 \%$ Acrylamide, $500 \mu 11 \mathrm{M}$ Tris Base-HCl pH 6.8, $40 \mu \mathrm{l} 10 \% \mathrm{SDS}, 40 \mu 110 \%$ APS, $\mathrm{ddH}_{2} \mathrm{O}$ up to $4 \mathrm{~mL}, 4 \mu \mathrm{TEMED}$ (see Note 13).

4. 2-propanol $100 \%$.

5. Deionized $\mathrm{H}_{2} \mathrm{O}\left(\mathrm{ddH}_{2} \mathrm{O}\right)$.

6. Clean absorbent paper.

7. Electrophoresis apparatus.

8. TGS $10 \times$ running buffer: $0.25 \mathrm{M}$ Tris Base, $1.92 \mathrm{M}$ Glycine, $1 \% \mathrm{SDS}$, pH 8.3 (see Note 14).

9. $5 \times$ Loading sample buffer ( $10 \mathrm{~mL}$ final volume): $1 \mathrm{~mL} 1 \mathrm{M}$ Tris Base- $\mathrm{HCl} \mathrm{pH} 6.8,1.4$ $\mathrm{mL} 10 \% \mathrm{SDS}, 2 \mathrm{~mL}$ of $20 \%$ glycerol, $2.5 \mathrm{~mL}$ of $25 \% \beta$-mercaptoethanol and $1 \%$ Bromophenol blue. Add water up to $10 \mathrm{~mL}$ and aliquot into clean $2 \mathrm{~mL}$ tubes (see Note 15). 
10. Coomassie staining solution: $0.2 \%$ Coomassie Brilliant-blue R, $25 \%$ 2-propanol and $10 \%$ acetic acid (see Note 16 ).

11. Destaining solution: $10 \%$ acetic acid, $30 \%$ denatured ethanol. Prepare $500 \mathrm{~mL}$ of destain solution adding $50 \mathrm{~mL}$ of acetic acid and $150 \mathrm{~mL}$ denatured ethanol to 300 $\mathrm{mL}$ of $\mathrm{ddH}_{2} \mathrm{O}$ (see Note 17).

\subsection{Immunoblotting and detection}

1. A spatula and clamps.

2. Nitrocellulose membrane $6 \mathrm{~cm} \times 9 \mathrm{~cm}$.

3. 6 absorbent filter paper $6 \mathrm{~cm} \mathrm{x} 9 \mathrm{~cm}$ for a single gel.

4. Plastic containers.

5. $10 \times$ Tris Base-glycine (see Note 18): $0.25 \mathrm{M}$ Tris Base $\mathrm{pH} 8.3,1.92 \mathrm{M}$ glycine.

6. $100 \%$ methanol.

7. Ponceau S.

8. $10 \times$ Phosphate buffered saline (PBS): $80 \mathrm{mM} \mathrm{NaHPO}$; $20 \mathrm{mM} \mathrm{NaH}_{2} \mathrm{PO}_{4} \times 2 \mathrm{H}_{2} \mathrm{O}$; $100 \mathrm{mM} \mathrm{NaCl}, \mathrm{pH} 7.2$.

9. 5\% milk-blocking solution: add $2.5 \mathrm{~g}$ skimmed milk to $50 \mathrm{~mL}$ of $1 \times$ PBS (see Note 19).

10. Anti-His tag antibody.

11. Chemiluminescent substrate.

12. Deionized $\mathrm{H}_{2} \mathrm{O}$.

\section{Methods}

Carry out all the procedures under sterile conditions unless otherwise specified.

\subsection{Cloning and propagation of the recombinant expression vector in Escherichia coli}

Prepare E. coli DH5a and BL21 (DE3) competent cells following the standard calcium chloride method (9) prior to cloning procedures: 
1. Streak E. coli from a glycerol stock or a liquid culture on a TY agar plate with a sterile loop and incubate the plate overnight at $37^{\circ} \mathrm{C}$.

2. Inoculate a single colony of $E$. coli in $5 \mathrm{~mL}$ of TY liquid medium and incubate overnight at $37^{\circ} \mathrm{C}$ with vigorous shaking.

3. Add $1 \mathrm{~mL}$ of the overnight $E$. coli culture to $99 \mathrm{~mL}$ of fresh $\mathrm{TY}$ liquid medium and incubate at $37^{\circ} \mathrm{C}$ with shaking until $\mathrm{OD}_{600} \mathrm{~nm}$ reaches 0.5 .

4. Place the culture on ice for 30 minutes then centrifuge at $4{ }^{\circ} \mathrm{C}$ at $4000 \mathrm{~g}$ for 10 minutes and discard the supernatant.

5. Gently resuspend the pellet with $100 \mathrm{~mL}$ ice-cold $50 \mathrm{mM} \mathrm{CaCl}_{2}$, then centrifuge at 4 ${ }^{\circ} \mathrm{C}$ at $4000 \mathrm{~g}$ for 10 minutes and discard the supernatant.

6. Resuspend the pellet with $50 \mathrm{~mL}$ of ice-cold $50 \mathrm{mM} \mathrm{CaCl}_{2}$ and incubate for 15 minutes on ice, then centrifuge at $4{ }^{\circ} \mathrm{C}$ at $4000 \mathrm{~g}$ for 10 minutes and pour off the supernatant.

7. Lastly, resuspend the pellet with $8.5 \mathrm{~mL}$ of ice-cold $50 \mathrm{mM} \mathrm{CaCl}_{2}$ and $1.5 \mathrm{~mL}$ of Glycerol (15\% final concentration) and place on ice for 1 hour.

8. Aliquot $400 \mu \mathrm{l}$ of the competent cells into sterile $2 \mathrm{~mL}$ tubes. The competent cells are ready to be used or can be stored at $-80^{\circ} \mathrm{C}$ (see Note 20 ).

Once E. coli competent cells are ready, subject your target DNA to PCR amplification using the following method:

1. In a $0.2 \mathrm{~mL}$ sterile tube combine $10-50 \mathrm{ng}$ of DNA target, $0.4 \mu \mathrm{M}$ of appropriate primers forward and reverse, $0.3 \mathrm{mM} \mathrm{dNTP}, 1 \times$ buffer (supplied by the manufacturer of the DNA polymerase), $1 \mathrm{U}$ of Taq DNA polymerase with proofreading activities. Prepare a negative control mix by adding the same reagents except for the DNA target in another $0.2 \mathrm{~mL}$ sterile tube.

2. Add the right amount of sterile water to reach $50 \mu 1$ final volume per reaction and gently pipette up and down.

3. Place the PCR samples into the thermocycler and start the PCR amplification program as follows: a) initial denaturation step at $94{ }^{\circ} \mathrm{C}$ for 5 minutes; b) denature 15 seconds at $94{ }^{\circ} \mathrm{C}$; c) anneals primers at $56{ }^{\circ} \mathrm{C}$ for 30 seconds; d) extend the DNA at $68{ }^{\circ} \mathrm{C}$ for 90 seconds; e) repeat steps b-d for 30 times; f) final extension at $68{ }^{\circ} \mathrm{C}$ for 5 minutes.

4. In the meantime prepare $1 \%$ agarose gel by mixing $1 \mathrm{~g}$ agarose with $100 \mathrm{~mL}$ of TAE $1 \times$ buffer previously prepared (see Note 22 ). 
5. Melt agarose by heating in a microwave oven until the solution boils and then leave the gel solution to cool at room temperature. Chill until the gel reaches approximately $50{ }^{\circ} \mathrm{C}$.

6. Gently pour the gel into a gel tray, add $0.5 \mu \mathrm{g} / \mathrm{mL}$ of ethidium bromide and evenly mix into the agarose gel with the help of a pipette tip.

7. Add the comb to one side of the gel and remove any bubbles in the solution.

8. Let the gel harden for approximately 20 minutes until it becomes milky and opaque. Remove the comb and soak the gel into an electrophoresis tank with $1 \times$ TAE running buffer.

9. Prepare the samples by adding $6 \times$ loading buffer to the DNA samples and the DNA ladder.

10. Load $5 \mu \mathrm{l}$ of the DNA target into the wells and close the lid of the electrophoresis chamber. Set the run at 120 volts (usually 30 minutes to 1 hour).

11. Visualize the gel under UV light to reveal the DNA bands.

12. Purify the PCR products with a PCR purification kit and proceed with the cloning step.

Prior to proceeding with the cloning step, digest both the DNA insert and the expression plasmid with the selected restriction enzymes applying the following digestion procedure:

1. add the following reagents in a sterile $1.5 \mathrm{~mL}$ tube: $1 \mu \mathrm{g}$ of DNA target, 10 units of the selected restriction endonuclease, $1 \times$ restriction enzyme Buffer (supplied by the manufacturer of the restriction endonuclease), sterile water to reach the $50 \mu$ l final volume. Gently mix by pipetting up and down.

2. Incubate the tube at $37^{\circ} \mathrm{C}$ for at least 1 hour.

3. Load $5 \mu \mathrm{l}$ of the digested DNA on $1 \%$ agarose gel, together with the undigested DNA $(100 \mathrm{ng})$ and run the gel by starting the electrophoresis process for 20 minutes at 200 volts (see Note 22).

4. Purify the digested DNA with a gel extraction kit.

5. Set up the ligation mixture reaction in a sterile tube using a 1:5 molar ratio of vector:insert DNA following the equation (see Note 21):

$$
(\text { ng of vector } \times k b \text { i insert } \div \text { kb i vector }) \times(\text { insert }: \text { vector molar ratio })
$$

6. Add the following reagents in a $20 \mu \mathrm{l}$ final volume: water, $1 \times$ ligation buffer (supplied by the manufacturer of the T4 ligase), DNA vector, DNA insert, T4 DNA ligase (1 unit). Mix gently ( $\mathrm{T}$ tube). Carry out a negative control mix containing all the reagents except the DNA insert (C tube). 
7. Incubate both ligation mixtures for 12 hours at $16{ }^{\circ} \mathrm{C}$.

8. Add $200 \mu \mathrm{l}$ of $E$. coli competent cells into the T tube gently pipette up and down. Do the same with the $\mathrm{C}$ tube.

9. Incubate on ice for 30-minute.

10. Heat-shock both tubes at $42{ }^{\circ} \mathrm{C}$ for 2 minutes and then transfer at room temperature for 5 minutes.

11. Add $800 \mu \mathrm{l}$ of prewarmed TY liquid medium and incubate at $37^{\circ} \mathrm{C}$ for 1 hour.

12. Spread 1:10 and 1:100 dilutions from the $\mathrm{T}$ and $\mathrm{C}$ tubes on $\mathrm{TY}$ agar plates containing $100 \mu \mathrm{g} / \mathrm{mL}$ ampicillin and incubate at $37^{\circ} \mathrm{C}$ for $12-15$ hours.

13. Inoculate 10 colonies obtained from the transformation of $E$. coli cells with $\mathrm{T}$ tube and 1 colony obtained from the transformation of $E$. coli cells with $\mathrm{C}$ tube (control colony), in $5 \mathrm{~mL}$ TY liquid medium supplemented with $100 \mu \mathrm{g} / \mathrm{mL}$ ampicillin and incubate at $37{ }^{\circ} \mathrm{C}$ for 12 hours with energetic shaking for the subsequent plasmid DNA extraction.

14. Centrifuge bacterial cultures at $10,000 \mathrm{~g}$ for 5 minutes and discard the supernatant.

15. Resuspend the pellet in $100 \mu \mathrm{l}$ of Solution 1 and incubate for 5 minutes at room temperature.

16. Add $200 \mu \mathrm{l}$ of Solution 2 and quickly place it on ice.

17. Add $150 \mu \mathrm{l}$ of $3 \mathrm{M}$ Sodium acetate and place on ice for 5 minutes.

18. Centrifuge at $10,000 \mathrm{~g}$ for 5 minutes and collect $400 \mu \mathrm{l}$ of supernatant into $2 \mathrm{~mL}$ sterile tubes.

19. Add 1 volume of phenol:chloroform:Isoamyl alcohol solution $(25: 24: 1, \mathrm{v} / \mathrm{v})$ and centrifuge at $10,000 \mathrm{~g}$ for 5 minutes.

20. Transfer the aqueous phases in a new $2 \mathrm{~mL}$ tube and add 3 volumes of Ethanol $(\mathrm{EtOH}) 100 \%(\mathrm{v} / \mathrm{v})$ and $1 / 10$ volume of $3 \mathrm{M}$ Sodium acetate.

21. Centrifuge at $10,000 \mathrm{~g}$ for 5 minutes and wash two more times using EtOH at $70 \%$ final concentration.

22. Discard the supernatant and let samples dry at room temperature.

23. Resuspend the pellet in $50 \mu \mathrm{l}$ of sterile water containing $20 \mu \mathrm{g}$ of RNase $(10 \mathrm{mg} / \mathrm{mL})$ and incubate at $37^{\circ} \mathrm{C}$ for 30 minutes.

24. Load $5 \mu \mathrm{l}$ of the isolated plasmid DNA on $1 \%$ agarose gel, together with $5 \mu \mathrm{l}$ of plasmid DNA extracted from the control colony and run the gel by starting the electrophoresis process for 20 minutes at 200 volts (see Note 22). 
25. Visualize the gel under UV light to reveal the DNA bands.

26. Digest the selected plasmid DNA with one or two one cutter restriction endonucleases based on the sequence of the recombinant plasmid, to verify the success of the cloning procedure and load the digested DNA on $1 \%$ agarose gel for 20 minutes at 100 Volts.

27. Prepare a glycerol stock of the strain containing the recombinant plasmid, by adding glycerol at $30 \%$ final concentration to the bacterial culture collected in step 13. Store it at $-80{ }^{\circ} \mathrm{C}$ (Figure 1).

28. Use 10-50 ng of the recombinant plasmid to transform E. coli BL21 (DE3) competent cells and to select the recombinant strain on TY agar plate supplemented with 100 $\mu \mathrm{g} / \mathrm{mL}$ ampicillin, as reported above.

\subsection{Expression and extraction of recombinant protein}

1. Inoculate a single BL21 (DE3) recombinant colony in $5 \mathrm{~mL}$ TY liquid medium containing ampicillin $100 \mu \mathrm{g} / \mathrm{mL}$ using a sterile loop and incubate the culture at $37^{\circ} \mathrm{C}$ for 12 hours.

2. Add $1 \mathrm{~mL}$ of the culture to $49 \mathrm{~mL}$ of fresh $\mathrm{TY}$ liquid medium and incubate at $37{ }^{\circ} \mathrm{C}$ with shaking until $\mathrm{OD}_{600} \mathrm{~nm}$ reaches 0.4 .

3. Split the cultures into 2 sterile flasks containing $25 \mathrm{~mL}$ of culture each one.

4. Add IPTG to a final concentration of $1 \mathrm{mM}$ only to one flask (labelled induced flask) and incubate both flasks at $37^{\circ} \mathrm{C}$ with vigorous shaking.

5. After 6 hour induction, collect the cultures from both flasks and centrifuge at 10,000 $\mathrm{g}$ for 10 minutes. Discard the supernatant.

6. Resuspend the pellets in 4 volumes of fresh and cold PBS-Triton X-100 $1 \%$ and aliquote the samples into clean $2 \mathrm{~mL}$ tubes.

7. Freeze in a dry ice-ethanol bath for 10 minutes. Immediately, thaw at $37^{\circ} \mathrm{C}$ water bath for 10 minutes.

8. Repeat step 7 for 5 times.

9. Centrifuge at $10,000 \mathrm{~g}$ for 15 minutes at $4{ }^{\circ} \mathrm{C}$.

10. Collect the supernatants into clean $2 \mathrm{~mL}$ tubes and resuspend the pellets with the same PBS-Triton X-100 1\% volumes used in step 6.

11. Quantify the protein concentration of the soluble (supernatant) and insoluble (pellet) fractions using the Bradford assay. Warm up the spectrophotometer before use.

12. Prepare a $0.1 \mathrm{mg} / \mathrm{mL}$ BSA stock solution to use as standard. 
13. Dilute the Bradford reagent 5-fold in deionized $\mathrm{H} 2 \mathrm{O}$ to minimize analysis bias.

14. Create the blank sample adding $1 \mathrm{~mL}$ Bradford reagent into a clean $2 \mathrm{~mL}$ tube.

15. Prepare the standard samples into $2 \mathrm{~mL}$ clean tubes using increasing concentrations of BSA to elaborate the standard curve (i.e. 2, 3, 6, $8 \mu \mathrm{g}$ ). When pipetting, be careful to release the samples at the bottom of the tube (see Note 23 ).

16. Add $1 \mathrm{~mL}$ Bradford reagent to all the BSA samples, mix well and incubate for 20 minutes at room temperature.

17. Dilute the unknown samples if necessary in deionized $\mathrm{H}_{2} \mathrm{O}$ (generally $10-100$ fold) to obtain approximately 5-50 $\mu$ g of protein.

18. Set up a triplicate of each unknown sample using increasing volumes (i.e. 20, 30, 40 $\mu \mathrm{l})$ to get approximately increasing protein concentration.

19. Add $1 \mathrm{~mL}$ Bradford reagent to all the unknown samples, mix well and incubate for 20 minutes.

20. With the help of Pasteur pipettes, transfer each sample into clean UV/VIS cuvettes to read the absorbance.

21. Use the blank sample as the zero to calibrate the spectrophotometer. Measure the absorbance of each sample (BSA standards and unknown samples) at $595 \mathrm{~nm}$.

22. Calculate the concentration of the unknown samples based on the linear equation of the standard curve.

23. Load $15 \mu \mathrm{g}$ of each soluble fraction or $15 \mu \mathrm{l}$ of each pellet fraction on SDS-PAGE gel and run the electrophoresis process as follows.

\subsection{Recombinant protein detection by SDS-PAGE}

The first step of SDS-PAGE consists of casting the polyacrylamide gel in two distinct layers: the stacking gel ( $5 \%$ ) and the resolving gel $(12.5 \%)$. The polyacrylamide gel is composed of $30 \quad$ acrylamide/bis acrylamide 29:1.

1. Assemble the glass plates and the spacer in the gel casting apparatus. Accurately mix the resolving gel mixture before pouring it into the glass plates. Make sure to reach a level below approximately $2 \mathrm{~cm}$ from the shorter plates.

2. Add a layer of 2-propanol $100 \%$ with the help of a pipette to avoid bubbles formation. This step also prevents the gel from drying out.

3. Let the resolving gel polymerize for 20 minutes at room temperature. 
4. Drain the 2-propanol $100 \%$, and add $\mathrm{ddH}_{2} \mathrm{O}$ to wash out any 2-propanol or gel residual. Wipe any residual water trapped into the glass plates with the help of clean absorbent paper.

5. Mix the stacking gel components and carefully pour the gel above the resolving gel to fill the glass plates. Insert the comb at the top of the gel.

6. Stand at room temperature for at least 20 minutes. Once the gel has polymerized, remove the comb and wash the wells with $\mathrm{ddH}_{2} \mathrm{O}$.

7. Place the casted gel into the electrophoresis apparatus and fill it with TGS $1 \times$ running buffer.

8. Accurately prepare the samples resuspending in $1 \times$ loading sample buffer.

9. Incubate the samples at $100{ }^{\circ} \mathrm{C}$ for 5 minutes. Add a protein marker into the first well and then load $15 \mu \mathrm{g}$ or $15 \mu \mathrm{l}$ of the samples into the wells.

10. Run the gel at $120 \mathrm{~V}$ until the samples reach the bottom of the gel. Stop the run and pick up the gel. Carefully remove the glass plate and place the gel into a plastic container. Wash the gel with $\mathrm{ddH}_{2} \mathrm{O}$.

11. Drain the water and add approximately $20 \mathrm{~mL}$ of Coomassie staining solution. Incubate 1 hour at room temperature with shaking.

12. Remove the staining solution and add $5 \mathrm{~mL}$ of destaining solution for 1 minute. Discard the destain solution and add $20 \mathrm{~mL}$ of destaining solution. Place at room temperature with shaking until completely destained. Wash with $\mathrm{ddH}_{2} \mathrm{O}$ and visualize (Figure 2).

\subsection{Recombinant protein detection by Western blotting}

To detect the recombinant fusion protein by western blot analysis, we use an anti-His antibody against the N-terminal His-tag. Separate the proteins by SDS-PAGE as reported above and then proceed with the electro-transfer. Be careful to avoid the staining step with Coomassie staining solution when performing Western blotting analysis.

1. Once the electrophoresis is completed, collect the gel with the help of a spatula and remove the stacking gel.

2. Place the gel and the nitrocellulose membrane in separate plastic containers with the $1 \times$ Tris Base-glycine, $20 \%$ methanol transfer buffer (see Note 24). Incubate for 30 minutes at $4{ }^{\circ} \mathrm{C}$. 
3. Assemble the transfer sandwich with the help of clean clamps and using absorbent filter papers. Rinse 3 filter paper into the transfer buffer and stack them on top of each other. Make sure the nitrocellulose membrane is on the cathode and the gel on the anode. Stack the other 3 filter paper rinsed into the transfer buffer onto the sandwich.

4. Eliminate any potential air bubbles trapped into the sandwich with the help of a roller.

5. Run the electro-transfer at $15 \mathrm{~V}$ for 30 minutes.

6. Shut the transfer machinery and pick up the membrane with the help of clean clamps. Place it into a plastic container.

7. To reveal the transferred bands, stain the membrane with Ponceau S dye for a couple of minutes.

8. Once the protein bands display, de-stain thoroughly with $1 \times$ PBS for further immunorevelation steps.

9. Incubate the membrane with $1 \times$ PBS-milk $5 \%$ blocking solution for 30 minutes on a shaker.

10. Add 1:1,000 HRP conjugate anti-His tag antibody to the blocking $5 \%$ solution and incubate for 1 hour.

11. Rinse the blot 3-4 times with $1 \times$ PBS for 5 minutes.

12. Reveal using the chemiluminescent substrate according to the manufacturer instructions.

13. Visualize the chemiluminescent signal using a CCD camera-based imager.

\section{Notes}

1. To prepare $400 \mathrm{~mL}$ of $\mathrm{TY}$ agar plate, weigh $7.4 \mathrm{~g}$ of agar and transfer it into a clean bottle. Adjust the volume to $400 \mathrm{~mL}$ using fresh TY liquid medium and autoclave. Let it cool at room temperature before pouring onto Petri dishes in sterile conditions.

2. We find that preparing this fresh each time will implement the results.

3. We find best results when using it sterile.

4. Primers are designed by using the web-based program Primer3. The forward primer includes 15-18 nucleotides complementary to the sequence of interest starting from its start codon and a selected restriction site at the 5 ' end. The reverse primer includes 15-18 nucleotides complementary to the sequence of interest starting from the stop 
codon and a selected restriction site at the 5' end of this primer. The restriction sites are chosen amongst that present in the Multi-Cloning-Site (MCS) of the vector and should guarantee that the DNA fragment is inserted in frame with the start codon of the expression vector

5. Before pouring onto Petri dishes, add $400 \mu 1$ ampicillin into a $400 \mathrm{~mL}$ TY agar plate. We maintain a ratio of 1:1,000 when adding ampicillin to medium or suspension. This means that for $1 \mathrm{~mL}$ of medium, $1 \mu \mathrm{L}$ of ampicillin $(100 \mu \mathrm{g} / \mathrm{mL})$ is added.

6. To prepare ampicillin $100 \mathrm{mg} / \mathrm{mL}$ stock, weigh $1 \mathrm{~g}$ of ampicillin (keep the powder stock stored at $4{ }^{\circ} \mathrm{C}$ ). Transfer into a sterile $15 \mathrm{~mL}$ falcon having care not to miss any granule of the ampicillin powder (help yourself with a washing flask). Add water up to $10 \mathrm{~mL}$. Vortex to help to dissolve ampicillin. Filter the solution with a $0.22 \mu \mathrm{M}$ filter and aliquot into sterile $2 \mathrm{~mL}$ tubes. Store at $-20^{\circ} \mathrm{C}$.

7. To prepare $500 \mathrm{~mL} 50 \times$ TAE, weigh $121 \mathrm{~g}$ of Tris Base and dissolve in approximately $300 \mathrm{~mL}$ of deionized water. Add $28.6 \mathrm{~mL}$ of $100 \%$ Glacial Acetic Acid and $50 \mathrm{~mL}$ of $0.5 \mathrm{M}$ EDTA. Tris Base will take a while to dissolve completely, thus we find it convenient to use it as the first ingredient. Store stock solution at room temperature.

8. Prepare Tris Base-HCl $1 \mathrm{M}$ solution and adjust the $\mathrm{pH}$ to 8 . Weigh $0.90 \mathrm{~g}$ of glucose and add to a becher containing $50 \mathrm{~mL}$ of water. Add $2.5 \mathrm{~mL}$ of Tris Base- $\mathrm{HCl} 1 \mathrm{M}, 2$ $\mathrm{mL}$ of $0.5 \mathrm{M}$ EDTA. Add water up to $100 \mathrm{~mL}$ and mix until dissolved. Adjust the $\mathrm{pH}$ to 8 if needed.

9. Mix $10 \mathrm{~mL}$ of $10 \% \mathrm{SDS}$ and $5 \mathrm{~mL}$ of $4 \mathrm{M} \mathrm{NaOH}$ into $8.5 \mathrm{~mL}$ of distilled water. Add deionized water up to $100 \mathrm{~mL}$.

10. Always use cold freeze EtOH. When preparing or handling EtOH wear gloves and a mask to prevent from inspiring any fumes. To prepare $100 \mathrm{~mL}$ of EtOH $70 \%$, add 30 $\mathrm{mL}$ of EtOH to $70 \mathrm{~mL}$ of deionized water. Store at $-20^{\circ} \mathrm{C}$.

11. To prepare RNAse A $10 \mathrm{mg} / \mathrm{mL}$ stock, weigh $10 \mathrm{mg}$ of RNAse A (keep the powder stock stored at $4{ }^{\circ} \mathrm{C}$ ). Transfer into a $2 \mathrm{~mL}$ sterile tube having care not to miss any granule of the RNAse powder (help yourself with a washing flask and a rack to stabilize the sterile tube). Add water up to $1 \mathrm{~mL}$. Vortex to help to dissolve the powder. Store at $-20^{\circ} \mathrm{C}$.

12. To prepare a stock of IPTG $100 \mathrm{mM}$, weigh $0.24 \mathrm{~g}$ of IPTG (keep the powder stock stored at $-20^{\circ} \mathrm{C}$ ). Transfer into a sterile $15 \mathrm{~mL}$ falcon tube having care not to miss any granule of the powder (help yourself with a washing flask). Add deionized water up to $10 \mathrm{~mL}$. Vortex to help to dissolve the powder. Filter the solution with a $0.22 \mu \mathrm{M}$ filter and aliquot into sterile $2 \mathrm{~mL}$ tubes. Store at $-20^{\circ} \mathrm{C}$.

13. In a $15 \mathrm{~mL}$ conical tube add the acrylamide, Tris Base- $\mathrm{HCl}$ and SDS. Carefully mix and then add APS. Reach the final volume by adding $\operatorname{ddH}_{2} \mathrm{O}$ and mix well. Add 
TEMED at last, evenly mix and pour it into the glass plates directly from the tube. This will lessen bubbles forming at the top of the gel. Always add TEMED as the last ingredient because this will initiate the polymerization reaction.

14. To prepare $100 \mathrm{~mL}$ stock of TGS $10 \times$, weigh $3 \mathrm{~g}$ of Tris Base and $14.4 \mathrm{~g}$ of Glycine. Transfer into a bottle and add $10 \mathrm{~mL}$ of $10 \%$ SDS. Add deionized water up to 100 $\mathrm{mL}$.

To prepare $1 \mathrm{~L}$ of TGS $1 \times$, add $100 \mathrm{~mL}$ of TGS $10 \times$ to $900 \mathrm{~mL}$ of $\mathrm{ddH}_{2} \mathrm{O}$ previously spilt into a cylinder. Seal the cylinder with parafilm and carefully mix upside down to evenly blend the ingredients.

15. Always store at $-20{ }^{\circ} \mathrm{C}$. When the solution is being used, place it on ice. We find it proper not to let the solutions sit at room temperature.

16. To prepare $400 \mathrm{~mL}$ of stain solution, add $0.8 \mathrm{~g}$ of Brilliant Blue $\mathrm{R}$ to $100 \mathrm{~mL}$ of 2 propanol and let the Coomassie powder dissolve completely. Add $40 \mathrm{~mL}$ of acetic acid and up to the final volume with $\mathrm{ddH}_{2} \mathrm{O}$.

17. Always wear gloves when handling acetic acid or ethanol and prepare the solution in a fume hood to avoid any fumes inhalation.

18. Always prepare a large stock of $10 \times$ Tris Base-glycine (as reported in Note 15 except for SDS) to store at room temperature.

19. Prepare $50 \mathrm{~mL}$ of $1 \times$ PBS-milk $5 \%$ blocking solution, weigh $2.5 \mathrm{~g}$ of skimmed milk and transfer into a falcon tube containing $50 \mathrm{~mL}$ of $1 \times$ PBS. Vortex the solution may help dissolve faster.

20. It seems to be common that competent cells may have low-efficiency transformation. We find that this issue can be sorted out by changing the molarity of $\mathrm{CaCl}_{2}$ or using fresh $\mathrm{CaCl}_{2}$, or resuspending more gently.

21. Frequently this ligation reaction step does not work as intended causing low or no recombinant colonies downstream the transformation step. Thus, troubleshoot modifying the vector:insert molar ratio for the insert as well as scaling down ng of the vector.

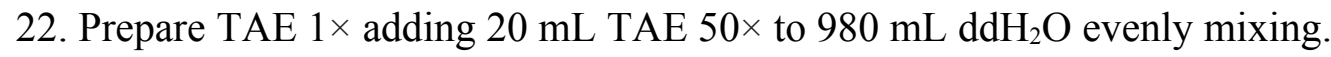

23. When performing the Bradford assay, put the samples first into the tubes (BSA standard or unknown) paying attention to release the sample completely and then add the Bradford reagent. It is recommended to use the same equipment throughout the assay to minimize biases that frequently can occur when handling with little volumes.

24. Prepare $1 \times$ Tris Base-glycine-20\% methanol in a becher adding $10 \mathrm{~mL} 10 \times$ Tris Base-glycine, $20 \mathrm{~mL}$ methanol $100 \%$ and $70 \mathrm{~mL} \mathrm{ddH}_{2} \mathrm{O}$. The gel and the nitrocellulose membrane must be thoroughly covered with the transfer buffer solution. 


\section{Acknowledgement}

This work was partially supported by the European Research Council (ERC) under the European Union's Horizon 2020 research and innovation programme (grant agreement No. 948972), NSF grant IOS 19-51690 and NASA grant 80NSSC21K0485. 


\section{References}

1. Binder MD, Hirokawa N, and Windhorst U, Eds, (2009) Heterologous Expression, In: Encyclopedia of Neuroscience, pp. 1830-1830 Springer, Berlin, Heidelberg

2. Frommer WB and Ninnemann O (1995) Heterologous Expression of Genes in Bacterial, Fungal, Animal, and Plant Cells. Annu Rev Plant Physiol Plant Mol Biol 46:419-444

3. Rosano GL and Ceccarelli EA (2014) Recombinant protein expression in Escherichia coli: advances and challenges. Front Microbiol 5

4. Chien A, Edgar DB, and Trela JM (1976) Deoxyribonucleic acid polymerase from the extreme thermophile Thermus aquaticus. J Bacteriol 127:1550-1557

5. Lawyer FC, Stoffel S, Saiki RK, et al (1989) Isolation, Characterization, and Expression in Escherichia coli of the DNA Polymerase Gene from Thermus aquaticus. J Biol Chem 264:6427-6437

6. Hofer U (2018) The majority is uncultured. Nat Rev Microbiol 16:716-717

7. Malmstrom RR and Eloe-Fadrosh EA Advancing Genome-Resolved Metagenomics beyond the Shotgun. mSystems 4:e00118-19

8. Mehlin C, Boni E, Buckner FS, et al (2006) Heterologous expression of proteins from Plasmodium falciparum: Results from 1000 genes. Mol Biochem Parasitol 148:144-160

9. Sambrook J and Russell DW (2006) The Condensed Protocols from Molecular Cloning: a Laboratory Manual, CSHL Press

10. Giovannelli D, Chung M, Staley J, et al (2016) Sulfurovum riftiae sp. nov., a mesophilic, thiosulfate-oxidizing, nitrate-reducing chemolithotrophic Epsilonproteobacterium isolated from the tube of Riftia pachyptila, a deep-sea hydrothermal vent tube worm. Int J Syst Evol Microbiol Submitted

11. Waite DW, Chuvochina MS, and Hugenholtz P (2019) Road Map of the Phylum Campylobacterota, In: Bergey's Manual of Systematics of Archaea and Bacteria, pp. 111 American Cancer Society 


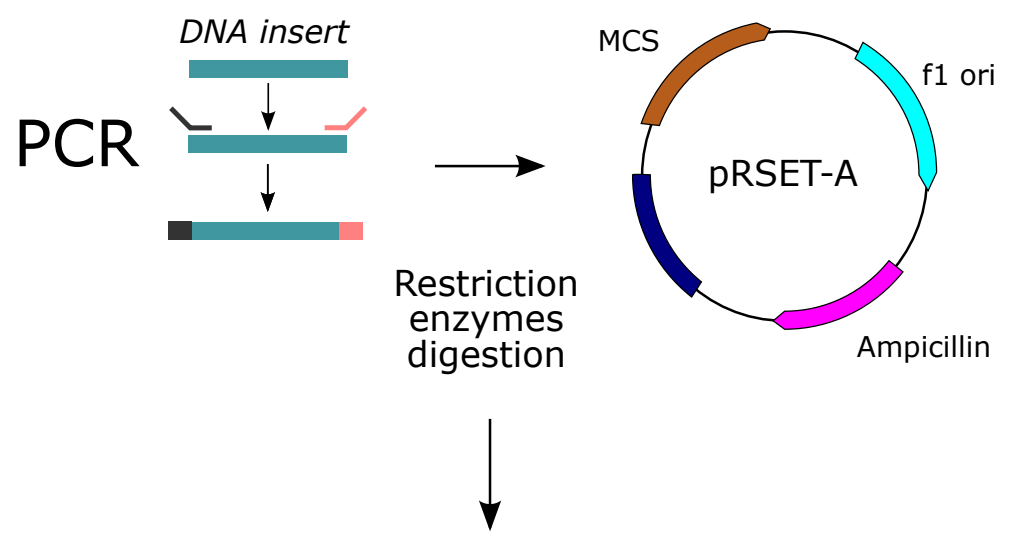

Ligation

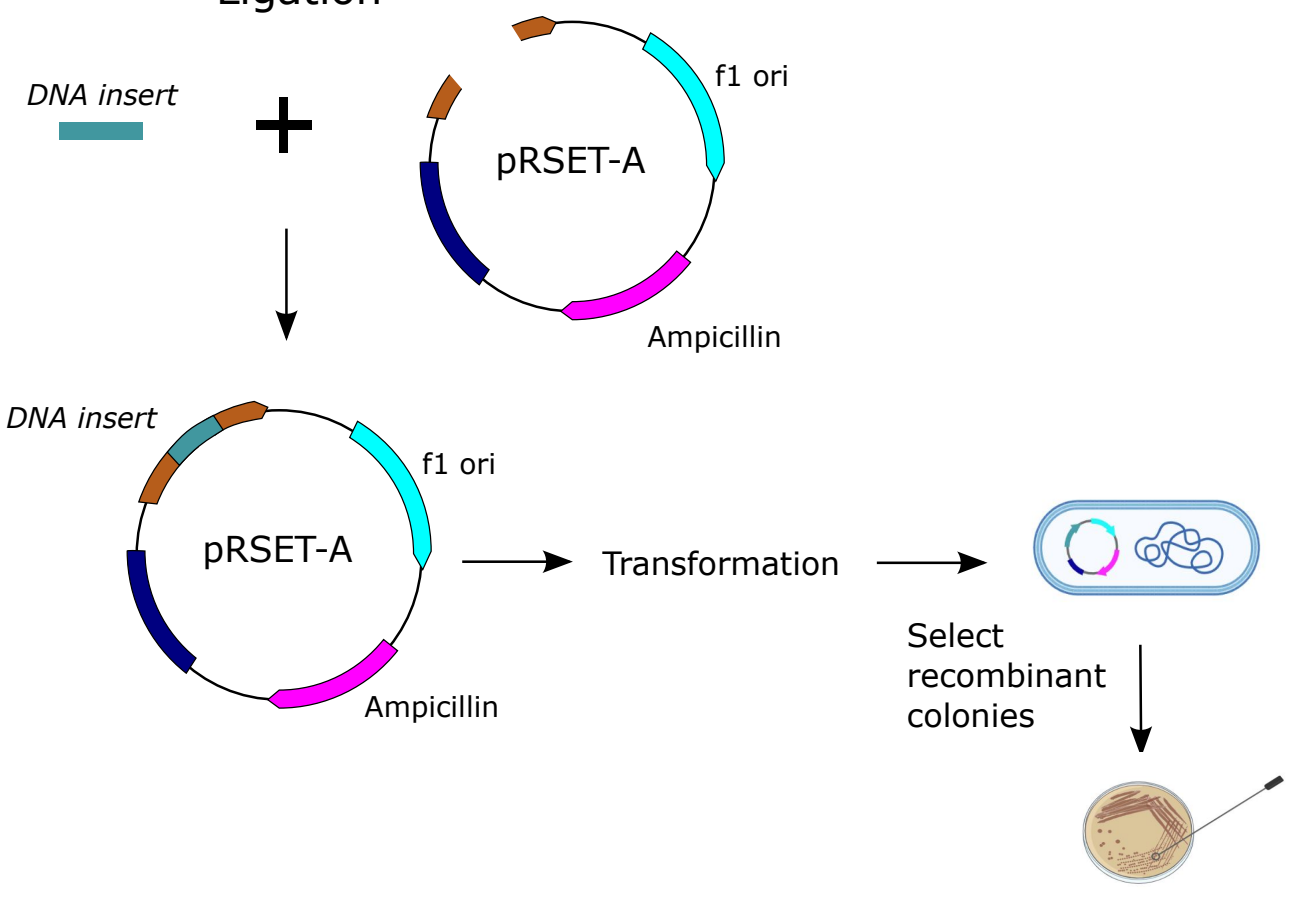

Figure 1. A simplified scheme of the cloning strategy applied to obtain the recombinant plasmid. Green and red lines indicate forward and reverse primers used for the PCR amplification step. The amplified products (PCR insert) and the expression vector (pRSETA) are subjected to digestion with the appropriate restriction enzymes, ligated thanks to the action of the T4 ligase enzyme, and cloned into E. coli DH5a host cells. The recombinant plasmid is then used to transform E. coli BL21 (DE3) competent cells. Ampicillin= ampicillin resistance gene; $M C S=$ multi cloning site. 


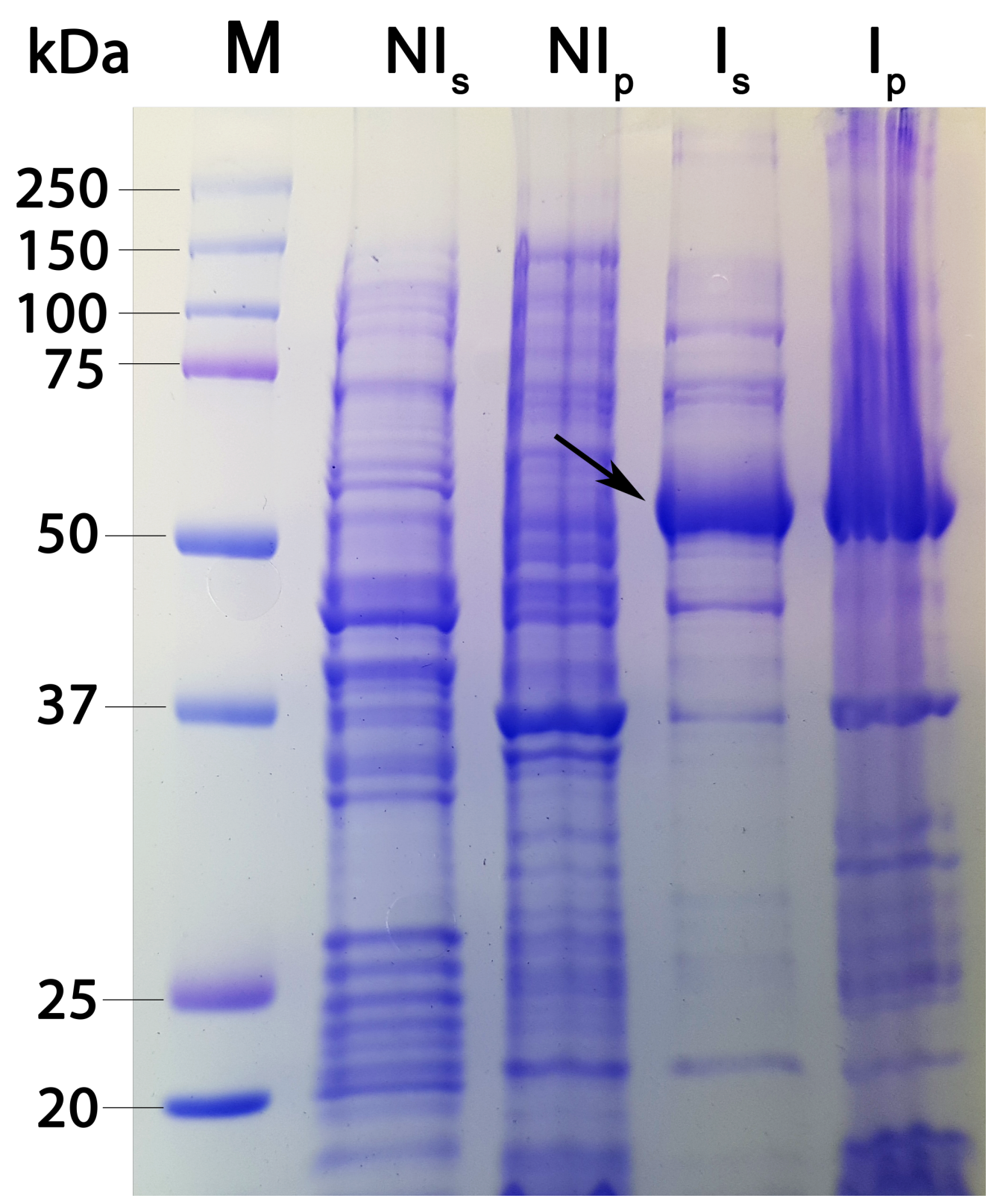

Figure 2. An example of SDS-PAGE analysis of soluble and insoluble proteins extracted from induced and uninduced cultures. The image represents an SDS-PAGE analysis of the expression of a novel putative collagenase from a marine microorganism Sulfurovum riftiae (10), class Epsilonproteobacteria (recently proposed to be reclassified as a new phylum Campylobacterota) (11). The arrow indicates a strong expression of the protein in the induced cultures. M: Protein marker (Precision Plus Protein Dual Color Standards, BIORAD); NI $_{\mathbf{s}}$ indicates soluble proteins extracted from the uninduced BL21 (DE3) strain carrying the recombinant plasmid; $\mathbf{N I}_{\mathbf{p}}$ indicates insoluble proteins extracted from the uninduced BL21(DE3) strain carrying the recombinant plasmid; $\mathbf{I}_{\mathbf{s}}$ indicates soluble proteins extracted from the induced BL21 (DE3) strain carrying the recombinant plasmid; $\mathbf{I}_{\mathbf{p}}$ indicates insoluble proteins extracted from the induced BL21 (DE3) strain carrying the recombinant plasmid. 